\title{
HENRY FAYOL'S PRINCIPLES OF MANAGEMENT AND BHAGAVAD GITA - A HERIMENEUTICS STUDY
}

KEY WORDS: Henry Fayol, Principles of Management, Bhagavad Gita, Division of work, Unity of Command, Equity

\section{Dr. Lavanya L}

Assistant Professor, Department of Business Administration, Mohamed Sathak College of Arts and Science

Hermeneutics is the study of interpretation. While taking up religious texts like Bhagavad Gita which provides abundance of knowledge, Hermeneutics is the choice of researcher. There have been various articles bringing out relevance of Bhagavad Gita in Management and most often researched is Leadership in Gita. The present article examines the untouched area of Henry Fayol's fourteen principles of Management and how Gita can be linked to some of these principles. Bhagavad Gita is presented in a question and answer format which is compiled into 18 chapters and contains 700 verses. This is a work which is believed to be more than 5000 years ago. Does this old work stand relevant and is this relevant to Management? This article brings out answers to these questions.

\section{Introduction:}

In the battlefield of Kuruskshetra, when Arjuna is faced with dilemma of fighting against his own Guru, mentors, brothers and relatives, Krishna reveals himself as the Lord and preaches the Bhagavad Gita. Gita is presented in a question and answer format which is compiled into 18 chapters and contains 700 verses. This is a work which is believed to be more than 5000 years ago. Does this old work stand relevant and is this relevant to Management? This article brings out answers to these questions.

\section{Background of the study:}

Henri Fayol, a French industrialist, is recognized as the Father of Modern Management. In the year 1916 Fayol wrote a book entitled "Industrial and General Administration". In this book, he gave the 14 Principles of Management.

\section{Division ofWork.}

2. Balancing Authority and Responsibility.

3. Discipline.

4. Unity of Command.

5. Unity of Direction.

6. Subordination of Individual Interests to the General Interest.

7. Remuneration.

8. Centralization

9. Scalar Chain.

10. Order.

11. Equity.

12. Stability of Tenure of Personnel.

13. Initiative.

14. Esprit De Corps.

As mentioned earlier, Bhagavad Gita is preaching of Lord Krishna to Arjuna when the latter is faced with a dilemma in the battlefield of Kurukshetra. This article attempts to link both these aspects and to find relevance of Gita in Management.

\section{Review of Literature:}

Shiv K. Tripathi (2007) in his research work, "Managing Business as a Spiritual Practice: The Bhagavad Gita way to Achieve Excellence through Perfection in Action", did a conceptual study to identify ways to supplement western framework of management principles and functions by incorporating the principles of three paths of human salvation recommended in the Bhagavad Gita.

Biswajit Satpathy (2010) in his research paper brings out Spiritual intelligence in Bhagavad Gita. Spiritual intelligence provides us with complete personality and truthfulness. It is the intelligence of our spirit. By the help of this intelligence, we contemplate over the basic questions of our life and reshape our answers. To resolve the conflict arising in the mind of Arjuna, Lord Krishna discussed about the four dimensions of conflict and awakened his soul through spiritual discourse. Spiritual intelligence is the fine-tuning of intellectual faculty and this is nonphysical and inspirational in nature. The Bhagavad-Gita teaches this wisdom. This paper has a review of literatures on spiritual intelligence and uses hermeneutics a qualitative research methodology, which is the interpretation of an ancient or a classical literature.

Shankar B. Chandekar (2012) Business Managements are guided by the mechanistic view of life which encourages fierce competition and 'survival of the fittest'. Managerial excellence is mostly centred round the final goal of creating "surplus" and fetching "maximum profit" for the owners who are at the top of the management. There is, however an awakening all over the world about the drawbacks of the Modern Art and Science of Management. A Holistic View of Management is gradually emerging; and a welcome shift in paradigm is on the horizon.

Anila KP and Dr. V.Krishnaveni (2017) mention that their purpose isn't to discard the Western model of efficiency, dynamism and striving for excellence, but to tune these ideals to India's holistic attitude of lokasangraha - for the welfare of many, for the good of many. There is indeed a moral dimension to business life. What we do in business is no different, in this regard, than what we do in our personal lives. The means don't justify the ends. Pursuit of results for their own sake is ultimately self-defeating.

Subhadeep Mukherjee (2017) mentions in his article that 'Bhagavad Gita' is one of the essential Indian ancient scriptures like Vedas, Purana's and Upanishads. It guides us by showing various spiritual paths through which we can gain self-knowledge as well as inner-peace. Many of our legendary leaders like Mahatma Gandhi, Dr. Radhakrishnan, Lokmanya Tilak and many more was influenced by the philosophy of 'Bhagavad Gita'. In his study the researcher showcases that, how 'Gita' influences the life of modern human society especially ' $\mathrm{Y}$ ' and ' $\mathrm{Z}$ ' generation. It also tried to analyze and highlight that, how Bhagavad Gita supports and develops certain management vision and thoughts, which has created a benchmark in the modern world as a key source for success to any organization or an individual.

Dr. Aswathi Nair (2019), The objective of the study is to understand the identity crisis and intrapersonal conflict management from the premise of Bhagavad Gita, an enviable product of ancient Indian classical literature written in Sanskrit Language. The research paper is based on a qualitative research analysis that encompasses an assessment, analysis and interpretation of literature on Identity Crisis and Intrapersonal Conflict management from carefully chosen verses of the Bhagavad-Gita. The 
methodology applied is called Vedic Hermeneutics. The topic is highly in demand and discussed across the C-Suite circles worldwide.

The above research extracts show that a lot of research has been done to understand relevance of Bhagavad Gita in Management.

\section{Research Gap:}

A detailed study of literature brings out that various aspects of Management have been linked with Bhagavad Gita and researchers have provided their thoughts and interpretation of the verses. However, it is noted that the fourteen principles of management propounded by Henry Fayol is taken up for study at the larger level. Hence, this article focuses on some of these Principles of Management and the relevant verses from Bhagavad Gita.

\section{Objectives of the Study:}

The objective of the study is as follows:

- To understand the link between Henry Fayol's Principles of Management and Bhagavad GitaTo gain insight on Management Perspective of Bhagavad Gita

- To suggest ways to implement the understanding in workplace context

\section{Methodology and Scope:}

This is a qualitative study and the methodology used is Hermeneutics. Hermeneutic research emphasizes subjective interpretations in the research of meanings of texts, art, culture, social phenomena and thinking. Thus, the strategy forms an opposite to those research strategies which stress objectivity and independence from interpretations in the formation of knowledge.

About Hermeneutics approach: The term hermeneutics is a

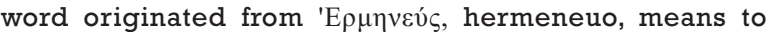
translate or interpret. The term is an English version of the classical Greek work hermeneus. Hermeneutics is understood as interpretation, the expression derived from the term of the Greek deity Hermes as the interpreter of the messages of the divinities. It was used for the interpretations of sacred scriptures of the Jewish, Biblical exegesis traditions Muslim and Hindu traditions.

The scope of the study is limited to certain Principles of Henry Fayol and not all the Principles.

\section{Limitations of the Study:}

1. Hermeneutics is subject to interpretation of the individual. The interpretations given to the verses depend on the understanding of the individual. The present study may have the researcher's limited understanding of the Bhagavad Gita.

2. The researcher has tried the interpretation only for a few principles and not all the fourteen principles.

3. The author has provided interpretation based on her understanding of Gita and may be subject to discussion.

\section{Analysis and Interpretation:}

Henry Fayol's 14 principles of Management (1916) is considered to be a pioneer work in terms of Management. Here's a look at some of the principles which seems to have a connection with preaching of Lord Krishna in our Baghavad Gita.

\section{Division of Work.}

chātur-varṇyaì mayā sṛiṣhtain guna-karma-vibhāgaśhah tasya kartāram api māì viddhyakartāram avyayam

Lord Krishna states he created 4 divisions in the society - four varnas namely Brahmana, Kshatriya, Vyshya and Sudra based on prominence of 3 Gunas - Satva, Rajas and Tamas for each varna. This is to ensure all societal work is assigned as a responsibility for people belonging to the particular varna.
This would help allocation of work like Kshatriyas would be warriors, Shudras would be worker/craftsmen and so on... this would ensure there is no overlapping of responsibilities. This can be interpreted in organisational context as the need to define the roles and responsibilities clearly.

\section{Unity of Command.}

mat-karma-krin mat-paramo mad-bhaktah sanga-varjitah nirvairah sarva-bhüteșh yah sa mām eti pāṇdava

-Bhagavad Gita, Chapter 11, Shloka 55

In this shloka, the Lord states that "Those who perform all their duties for my sake, who depend upon me and are devoted to me, who are free from attachment, and are without malice toward all beings, such devotees certainly come to me." Translating this to organisational context, the employer or the manager should be the only person issuing the command or instructions so that there are no confusions and employees work towards the goals of the organisation with a single focus.

III.Subordination of Individual Interests to the General Interest.

saha-yajñăh prajāh ș̣iṣhțva purovācha prajāpatị anena prasaviṣhyadhvam eșha vo 'stviṣhṭa-kāma-dhuk

-Bhagavad Gita, Chapter 3, Shloka 10

Here, Lord Krishna states, "In the beginning of creation, Brahma created humankind along with duties, and said, "Prosper in the performance of these yajñas (sacrifices), for they shall bestow upon you all you wish to achieve." Sacrifice is the selfless sacrifice and done by an individual for the benefit of the society or for larger interests. The same can be held true for an organisation; only if all the employees work towards organisational goals, company can be run successfully.

There is one more sloka from Vidhura Needhi which goes like this -

tyajet kulArthe puruSham grAmasyArthe kulam tyajet | grAmam janapadasyArthe AtmArthe pRithivIm tyajet

- Vidhura Needhi, Chapter 5, Shloka 17

This means renounce one person for the sake of the family, a family for the sake of village; village for the sake of country and even the [kingdom of] earth for saving a person's soul. This can be interpreted that smaller interests need to sacrificed for larger interests or results.

\section{Discipline}

asanśhayaì mahā-bāho mano durnigrahaì chalam abhyāsena tu kaunteya vairägyena cha grihyate

-Bhagavad Gita, Chapter 6, Shloka 35

This shloka in which Lord Krishna says, "O mighty-armed son of Kunti, what you say is correct; the mind is indeed very difficult to restrain. But by practice and detachment, it can be controlled." brings out that discipline is the way to success. Controlling of mind and focusing on work would be the best way to achieve organisation's goals.

\section{Equity}

ye yathā māim prapadyante tāns tathaiva bhajāmyaham mama vartmānuvartante manuṣhyāh pārtha sarvaśhah -Bhagavad Gita, Chapter 4, Shloka 11

Lord Krishna says "In whatever way people surrender unto me, I reciprocate with them accordingly. Everyone follows my path, knowingly or unknowingly, O son of Partha." Just like God treats all forms of creatures equally based on their service (work) done, similarly, a Manager should ensure that he is treating all the employees at par based on their work done and be impartial.

Findings of the study:

1. The study reveals that our scriptures have shown us 
guidelines on Management thousands and thousands of years ago. A similar finding is revealed in a research by Smitha Pillai, Sharnam Agrawal, Pranav Pillai (2019) in their article mention that In the Bhagavad Gita, they noticed that two types of knowledge physical (art, science, management, etc) and spiritual (mind, body and soul) which plays an important role in building character of an individual and a community as a whole. The article explains the relevance of Gita in Management.

2. Indian scriptures are treasure of knowledge and the managers can take lessons from it.

3. The present study reveals that some principles can have a direct connotation from Bhagavad Gita

\section{Suggestions:}

1. It is suggested that the Managers can take inspiration from the spiritual texts than just relying on western concepts.

2. The next generation of students, the so called Digital natives will be out of touch with our scriptures if not taught at an early stage. So, it is important they are educated at the school level on this.

\section{Conclusion:}

The researcher has attempted to related the Principles of Management with Bhagavad Gita preachings. The questions raised by Arjuna and answered by Lord Krishna till date answers the questions of many of our thoughts. This can be translated to work place context and applied based on the situation.

\section{References:}

1. https://www.speakingtree.in/blog/division-of-labour-in-ancient-society

2. https://www.eaglespace.com/spirit/gita_castesystem.php

3. https://www.holy-bhagavad-gita.org/

4. George, Theodore, "Hermeneutics", The Stanford Encyclopedia of Philosophy (Winter 2020 Edition), Edward N. Zalta (ed.), URL = <https://plato.stanford. edu/archives/win2020/entries/hermeneutics/>.Hermeneutic Research, https://koppa.jyu.fi/avoimet/hum/menetelmapolkuja/en/methodmap/stra tegies/hermeneutic-research

5. Graham McCaffrey, RN, PhD, Shelley Raffin-Bouchal, RN, PhD, Nancy J.Moules, $\mathrm{RN}, \mathrm{PhD}$, Hermeneutics as Research Approach: A Reappraisal, First Published July 1,2012 Research Article,

https://journals.sagepub.com/doi/10.1177/160940691201100303

6. Biswajit Satpathy (2010), Spiritual intelligence from the Bhagavad-Gita for conflict resolution, International Journal of Indian Culture and Business Management, 2010Vol.3 No.4,pp.449-465

7. Dr. Aswathi Nair (2019), Identity Crisis and Intrapersonal Conflict Management-The Bhagavad Gita Way, Adalya Journal, Volume 8, Issue 10 , October 2019

8. Subhadeep Mukherjee (2017), Bhagavad Gita: The key source of modern management, Asian Journal of Management 8(1):68-72, DOI: 10.5958/23215763.2017.00010.5

9. Sujit Kumar Acharya (2015), Lessons in Management From Bhagavad Gita International Journal of Research and Development - A Management Review (IJRDMR), ISSN (Print): 2319-5479,Volume-4, Issue-2, 2015

10. Tripathi, Shiv K., 2007. Managing Business as a Spiritual Practice: The Bhagwadgita way to Achieve Excellence through Perfection in Action. In: Sengupta, Sunita Singh and Fields, Dail (ed). Integrating Spirituality and Organisational Leadership. New Delhi: Macmillian India Ltd, pp. 221-231.

11. Shankar B. Chandekar (2012), Principles of Management and the Bhagavad Gita, Journal of Dharma (ISSN 0253-7222) Vol 37 No 1 (2012)

12. Anila KP and Dr. V.Krishnaveni (2017), A Study on Relationship between Principles of Management and Bhagavad Gita, International Journal of Advance Research in Computer Science and Management Studies, Vol.5, Issue3, March 2017, ISSN:2321-7782 